\title{
Evaluation of seed germination development and initial growth of cotton plants exposed to cadmium
}

Pedro Silva dos Santos ${ }^{1}$, Maria de Fátima de Souza Guilherme ${ }^{2}$, Laianne de Souza Guilherme ${ }^{3}$, José Lucas dos Santos-Oliveira ${ }^{4} \&$ Edevaldo da Silva ${ }^{4,5}$

1 Instituto Federal de Educação, Ciência e Tecnologia do Rio Grande do Norte, Currais Novos, Rio Grande do Norte, Brazil.

2 Universidade Federal de Campina Grande, Unidade Acadêmica de Ciências Biológicas, Patos, Paraíba, Brazil.

3 Instituto Federal de Educação, Ciência e Tecnologia do Rio Grande do Norte, Currais Novos, Rio Grande do Norte, Brazil.

4 Universidade Federal da Paraíba, Programa de Pós-Graduação em Desenvolvimento e Meio Ambiente, João Pessoa, Paraíba, Brazil.

5 Universidade Federal de Campina Grande, Unidade Acadêmica de Ciências Biológicas, Patos, Paraíba, Brazil.

\author{
Correspondence \\ E. da Silva \\ E-mail: edevaldos@yahoo.com.br \\ Received: 4 June 2021 \\ Accepted: 1 July 2021 \\ Published on-line: 22 October 2021
}

\section{Resumen}

Evaluación de la germinación de semillas y desarrollo inicial de las semillas de algodón expuestas al cadmio

Esta investigación evaluó los efectos fitotóxicos del cadmio en el desarrollo germinativo y el crecimiento inicial de Gossypium hirsutum L. Se evaluaron los efectos ecotoxicológicos de 13 concentraciones experimentales de cadmio $(0.0-50.0 \mathrm{mM})$ sobre variables de respuesta como porcentaje de germinación (IVG), tiempo promedio de germinación (TMG) y longitud de la raíz de las plántulas. Las semillas de G. hirsutum expuestas al cadmio mostraron una disminución en el porcentaje de germinación y un aumento en el número de plántulas anormales con las concentraciones 18.0 y 3.0 $\mathrm{mM}$, respectivamente, además de inhibir el crecimiento de la raíz y elevar el TMG de la exposición a 0,5 mM, reduciendo el IVG. G. hirsutum es una especie tolerante al cadmio durante su desarrollo germinativo.

Palabras clave: Contaminación; Gossypium hirsutum; Metal pesado.

\section{Abstract}

This research evaluated the phytotoxic effects of cadmium on the germination development and initial growth of Gossypium hirsutum L. The ecotoxicological effects of 13 experimental concentrations of cadmium (0.0-50.0 mM) on variables like germination percentage, GSI, average germination time (AGT) and root length were evaluated. G. hirsutum seeds exposed to cadmium showed a decrease in germination percentage and an increase in the number of normal plantules from the concentrations 18.0 and $3.0 \mathrm{mM}$, respectively. It also inhibited root growth and increased the AGT from the exposure to the concentration $0.5 \mathrm{mM}$, reducing the $\mathrm{GSI}$. G. hirsutum is tolerant to cadmium during its germinal stage.

Key words: Contamination; Gossypium hirsutum; Heavy metal. 


\section{Introduction}

Cotton (Gossypium hirsutum L.), belonging to the family Malvaceae, is a species cash crop cultivated in various regions of the world. It has a great importance for Brazilian economy as an agricultural product (Sousa, 2010), and its fibers generate sources of income for local and national farmers (Pereira et al. 2012).

For farmers, the analysis of seed quality and how seeds behave when sown is of great importance (Ferreira \& Novembre, 2016). Therefore, studies on seed germination are important to improve the morphological and physiological knowledge of embryos and plantules by analyzing especially the environmental conditions to which they are exposed (Gordin et al. 2012).

Environmental factors influence the germination and development of the seedlings (Guilherme et al. 2015). The presence of chemical contaminants, such as toxic heavy metals, in the substrate may interfere with or inhibit important physiological events in organisms.

Pollution of soils by heavy metals originates mainly from human activities such as industry, mining and agriculture. Cadmium is one of the heavy metals that cause harm to plants and animals (Melo et al. 2014). The effects of cadmium on plants vary with exposure time to metal, and may cause morphological, physiological and structural changes in plants, inducing enzymatic and metabolic changes (Augusto et al. 2014) or inhibiting the development of the embryonic axis and roots (Guimarães et al. 2008).

The presence of cadmium in the soil in a concentration that causes significant inhibitory effects on plants may be a source of chemical stress limiting a good agricultural productivity.

Several studies have reported the influence of cadmium on cotton (Ozyigit et al., 2013; Chen et al., 2015; Farooq et al., 2016; Liu et al. 2016; An et al., 2020). In general, these studies report biochemical, anatomical and genetic effects in organs of already developed and exposed plantules. Most of them do not report cadmium effects on germination and initial establishment of this species, so that the limiting effects of cadmium on the establishment of the species can be known. Thus, knowing the amounts of cadmium potentially toxic to agricultural crops, such as cotton, is important because they can guide decision-making on the appropriate choice of the species to be cultivated in a soil with an indication of contamination by this metal.

The aim of this research was to evaluate the phytotoxic effects of cadmium on the germination and initial growth of cotton seeds.

\section{Materials and methods}

The study was conducted at the Laboratory for Environmental Research (LAPAM) at the Federal University of Campina Grande, in the campus of Patos, Paraíba state, between September and December 2015.

Cotton seeds (variety BRS-286) were obtained from the Brazilian Agricultural Research Company (EMBRAPA), Campina Grande, Paraíba state. Its pre-treatment consisted in delinting with sulfuric acid (1 $\mathrm{L}$ of $\mathrm{H}_{2} \mathrm{SO}_{4}$ P.A./6.5 kg of seeds) for 5 minutes, followed by a wash in distilled water and neutralization of the residual acid with sodium bicarbonate $\left(\mathrm{NaHCO}_{3}\right.$ at $\left.10 \%\right)$ for 40 seconds, and drying in the sun for 30 minutes (Lopes et al. 2006). Delinted seeds were disinfected with sodium hypochlorite ( $\mathrm{NaClO}$ at $2.5 \%$ ) for $15 \mathrm{~min}$ utes and subjected to a germination viability test (Brasil, 2009).

Upon evaluating the effect of cadmium, 13 experimental concentrations $(0.0,0.5,1.0,3.0$, $6.0,9.0,12.0,15.0,18.0,21.0,30.0,40.0$ and 50.0 $\mathrm{mM}$ ) were analyzed in quadruplicate with 25 seeds in each plate, totaling 1,400 seeds. This concentration range was defined from the experimental concentration ranges reported in studies with this metal and confirmed to be relevant in a pilot experiment with germination at concentrations of $0.5,5.0,25.0 ; 50.0$, and $75.0 \mathrm{mM}$.

Seeds were immersed for 30 minutes in $20 \mathrm{~mL}$ of each experimental concentration and sown in Petri dishes (Ø $150 \mathrm{~mm})$ over a sterilized double layered germitest paper $\left(105{ }^{\circ} \mathrm{C}\right.$ for $\left.120 \mathrm{~min}\right)$, dampened with $8 \mathrm{~mL}$ of distilled water. The plates were sealed with plastic film to prevent loss of moisture.

Experimental cadmium solutions were prepared using cadmium sulfate $\left(\mathrm{CdSO}_{4} .8 \mathrm{H}_{2} \mathrm{O}\right)$, keeping the $\mathrm{pH}$ of the solution at approximately 6.0. The control experiment contained only distilled water.

The experiment was conducted under labora- 
tory conditions (on the bench), where the treatments were exposed to the photoperiod $8 \mathrm{~h}$ light and $12 \mathrm{~h}$ dark, under white fluorescent light. The room temperature was monitored twice daily and varied $28 \pm 2{ }^{\circ} \mathrm{C}$ with an average of $60 \%$ relative humidity.

The following variables were analyzed: germination speed index (GSI), average germination time (AGT), percentage of germination and abnormal plantules, root growth and biomass production with fresh and dry matter (Maguire, 1962).

There was a daily monitoring of the count of germination and abnormalities of plantules (BRASIL, 2009). The root length was measured with a digital caliper at the beginning of germination (48 hours) and when the germination percentage became constant $(120 \mathrm{~h})$.

Root lengths were obtained by measuring 8 plantules in each plate, totaling 32 seedlings per experimental concentration, and were expressed in millimeters. Fresh and dry matters were determined according to BRASIL (2009). The dry matter was obtained after drying at $105{ }^{\circ} \mathrm{C}$ and was expressed in grams.

The results were statistically evaluated using the statistical software SPSS 20.0. When necessary, data were transformed in arc-sine $[(x+0.5) /$ $100]^{0.5}$ to ensure the homoscedasticity of data, which were evaluated by two-way analysis of variance (ANOVA) followed by a Tukey test to determine the statistical significance of the difference between the variances. The analysis of the growth of seedling parts over time was performed using the polynomial regression model. For all statistical analyses, a significance level of $p<0.05$ was adopted.

\section{Results and discussion}

The viability of the analyzed seeds reported average values of $94 \pm 5.0 \%$. According to Brazil (2009), this value confirms that the seeds are viable for germination.

G. hirsutum seeds showed a significant decrease in germination percentage when exposed to the cadmium concentration $21.0 \mathrm{mM}$, with a $10 \%$ decrease compared to control, achieving a decrease of $82 \%$ in the exposure to the concentration $50 \mathrm{mM}$ (Fig. 1).

However, despite a good germination, the presence of normal plantules was observed at a

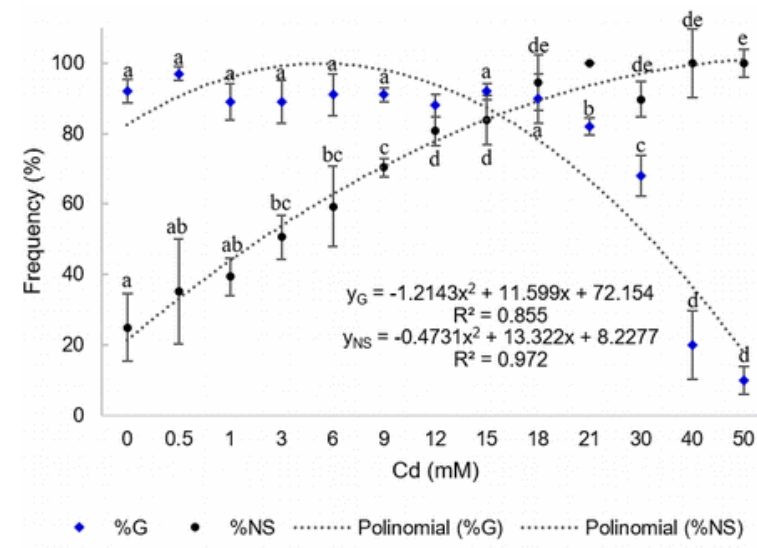

Figura 1. Porcentaje de germinación $(\% \mathrm{G})$ y plántulas normales (\%NS) de semillas de Gossypium hirsutum expuestas a diferentes concentraciones de cadmio.

Figure 1. Germination percentage $(\% \mathrm{G})$ and percentage normal plantules (\%NS) of Gossypium hirsutum seeds exposed to different cadmium concentrations.

high frequency, significantly different from the control $(\mathrm{F}=10.972, \mathrm{p}<0.001)$, from the concentration $3.0 \mathrm{mM}(50.6 \%)$, reaching $100 \%$ of abnormal plantules at the concentration $21 \mathrm{mM}$, respectively. The types of abnormalities observed and their percentage were often (Fig. 2) short and coarse primary roots $(56.5 \%)$ and thin and weak primary roots $(27.6 \%)$.

There was a significant correlation among cadmium concentrations to the decrease in germination percentage, and the increase in the number of abnormal plantules (Fig. 1).

The variables GSI and AGT were negatively influenced by the presence of cadmium, recording a significant decrease from the concentrations $0.5 \mathrm{mM}$ and $30 \mathrm{mM}$, respectively (Table 1). The polynomial regression analyses confirmed the correlations between the change in GSI and AGT according to the increase in the concentration of cadmium.

The root growth, after 24 hours of sowing, decreased $(F=10.972, p<0.0001)$ from the concentration $0.5 \mathrm{mM}$. This change was most evident after 72 hours of exposure (Fig. 3), with a $50 \%$ inhibition of root growth from the concentration $3.0 \mathrm{mM}$ in relation to the control, reaching $100 \%$ of inhibition in plantules exposed to the concentration $40.0 \mathrm{mM}$.

These results suggest that plantules susceptible to cultivation in the field with a soil contaminated by cadmium may have a decreased root growth and consequently a reduced ability to absorb nutrients and soil moisture. This may hinder the 

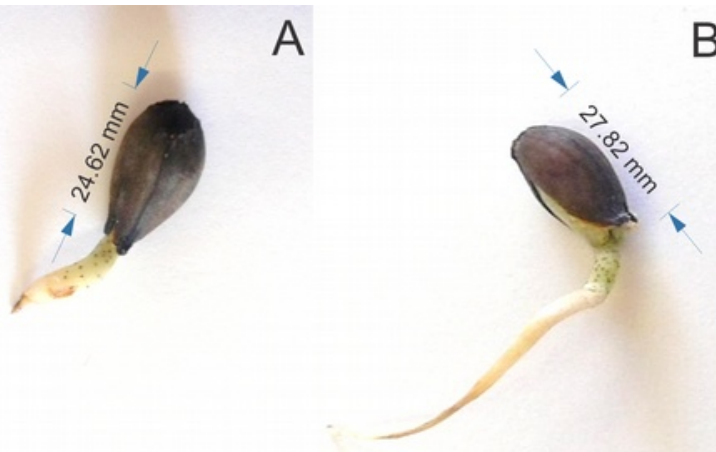

Figura 2. Imágenes de los tipos de anormalidades observadas en plántulas de Gossypium hirsutum. A: raíces primarias cortas y gruesas; B: raíces primarias finas y débiles.

Figure 2. Images of the types of abnormalities observed in Gossypium hirsutum plantules. A: short and coarse primary roots; B: thin and weak primary roots.

\begin{tabular}{ccc}
\hline Concentration & GSI & AGT \\
\hline 0.0 & $14.27 \pm 2.03^{\mathrm{b}}(14.2)$ & $2.00 \pm 0.34(17.0)$ \\
0.5 & $12.58 \pm 0.83^{\mathrm{ab}}(6.6)$ & $2.49 \pm 0.24^{\mathrm{ab}}(9.4)$ \\
1.0 & $12.02 \pm 2.15^{\mathrm{ab}}(17.9)$ & $2.39 \pm 0.38^{\mathrm{ab}}(16.1)$ \\
3.0 & $11.71 \pm 0.71^{\mathrm{ab}}(6.1)$ & $2.38 \pm 0.16^{\mathrm{ab}}(6.6)$ \\
6.0 & $11.63 \pm 1.00^{\mathrm{ab}}(8.6)$ & $2.46 \pm 0.14^{\mathrm{ab}}(5.7)$ \\
9.0 & $11.02 \pm 1.20^{\mathrm{ab}}(10.9)$ & $2.55 \pm 0.17^{\mathrm{ab}}(6.8)$ \\
12.0 & $11.67 \pm 1.59^{\mathrm{ab}}(13.7)$ & $2.28 \pm 0.21^{\mathrm{ab}}(9.4)$ \\
15.0 & $10.46 \pm 1.27^{\mathrm{ab}}(12.2)$ & $2.65 \pm 0.14^{\mathrm{ab}}(5.3)$ \\
18.0 & $10.85 \pm 0.71^{\mathrm{ab}}(6.6)$ & $2.46 \pm 0.07^{\mathrm{ab}}(2.9)$ \\
21.0 & $10.83 \pm 1.91^{\mathrm{ab}}(17.7)$ & $2.27 \pm 0.27^{\mathrm{ab}}(12.0)$ \\
30.0 & $5.29 \pm 0.67^{\mathrm{ab}}(12.8)$ & $3.61 \pm 0.12^{\mathrm{ab}}(3.3)$ \\
40.0 & $1.63 \pm 0.31^{\mathrm{a}}(18.7)$ & $3.88 \pm 0.33^{\mathrm{a}}(8.6)$ \\
50.0 & $0.66 \pm 0.30^{\mathrm{a}}(34.6)$ & $4.21 \pm 1.18^{\mathrm{a}}(28.1)$ \\
\hline Polynomial & $\mathrm{y}=-0.1254 \mathrm{x}^{2}+$ & $\mathrm{y}=0.0233 \mathrm{x}^{2}-0.19 \mathrm{x}+$ \\
equation & $0.8184 \mathrm{x}+11.793$ & 2.602 \\
$\mathrm{R}^{2}$ & $\mathrm{R}^{2}=0.8648^{*}$ & $\mathrm{R}^{2}=0.7867^{*}$ \\
F ANOVA & $34.369^{*}$ & $12.232^{*}$ \\
\hline Mean \pm SD (percent coefficient of variation) \\
Different letters indicate significant difference among values in the \\
same column (p<0.05). ${ }^{*}$ Significant at $\mathrm{p}<0.001$
\end{tabular}

Tabla 1. Índice de velocidad de germinación (GSI) y tiempo promedio de germinación (AGT) de semillas de algodón expuestas al cadmio. Experimentar.

Table 1. Germination speed index (GSI) and average germination time (AGT) of cotton seeds exposed to different concentrations of cadmium.

growth and establishment of the plants.

Cadmium also influenced the biomass production. Compared to the control, there was a significant $(\mathrm{p}<0.001)$ reduction in fresh $(\mathrm{F}=26.499)$ and dry mass $(\mathrm{F}=1,526.28)$, where this effect was observed from $6.0 \mathrm{mM}$, respectively (Fig. 4). Linear regression analysis confirms high correlation between reduction of biomass and increasing concentrations of cadmium (Fig. 4).

Studies with $G$. hirsutum also recorded efects on the germination depending on cadmium doses (Aycicek et al. 2008a; Aycicek et al. 2008b). Several studies reported the toxic effects of cadmium to others crops. In the evaluation of the toxic
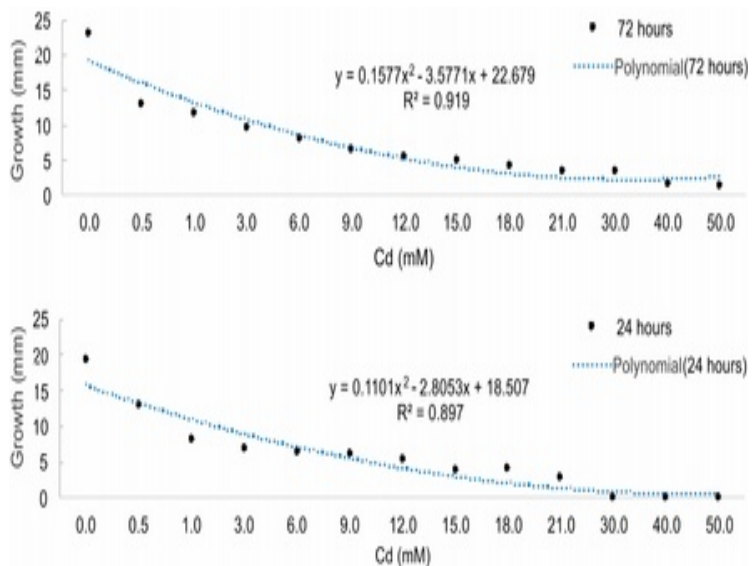

Figura 3. Crecimiento de las raíces después de 24 hy 72 h de la siembra de semillas de Gossypium hirsutum.

Figure 3. Root growth after $24 \mathrm{~h}$ and $72 \mathrm{~h}$ from the sowing of Gossypium hirsutum seeds.

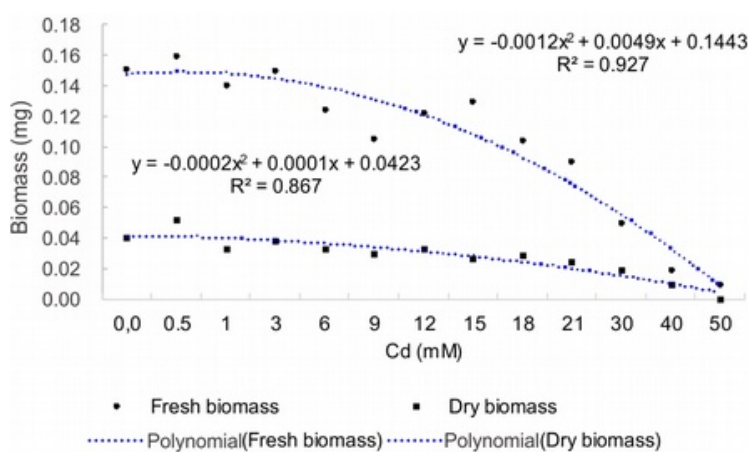

Figura 4. Influencia del cadmio en la producción de biomasa fresca y seca de plántulas de Gossypium hirsutum.

Figure 4. Cadmium influence on the production of fresh and dry biomass of Gossypium. hirsutum plantules.

effects of cadmium in Sinapis arvensis L., a decrease in seed germination percentage $(5.6 \%)$ was observed for the concentration $1.0 \mathrm{mM}$ (Heidari \& Sarani, 2011).

In a study by Tao et al. (2015), involving several crop species exposed to cadmium (0.0-3.2 $\mathrm{mM}$ ), it showed significant variations in the percentage of germination. In relation to root length, these species, when exposed to the concentration $3.2 \mathrm{mM}$, underwent the following growth decrease percentages: soybean (Glycine max (L.) Merr.): $25 \%$, mung bean (Vigna radiata L.): $20 \%$, beans (Vigna angularis (Willd.) Ohwi \& Ohashi): $27 \%$, lentils (Lablab purpureus L.): $38.5 \%$, sweet pea (Lathyrus odoratus L.): $23 \%$, and black beans (Dumasia villosa DC.): $33 \%$. The results reported here for $G$. hirsutum seeds reveal that it is more tolerant than these crop species.

The presence of abnormalities in the roots of G. hirsutum seedlings exposed to cadmium are similar to the results reported by Wilhelm et al. 
(2015), who observed a higher occurrence of abnormal seedlings in Triticum aestivum L. when exposed to cadmium, and a decrease in root length of seedlings from the concentration $0.12 \mathrm{mM}$.

The inhibition of root growth is one of plants' responses to exposure to cadmium, and occurs more rapidly than other physiological responses (Gonçalves et al. 2009). This toxic effect is observed in roots, being reported for several species of plants, such as Spinacia oleracea L. (Hosseini et al. 2012), Cicer arietinum L. (Faizan et al. 2011), T. aestivum (Guilherme et al. 2015) and Solanum tuberosum L. (Gonçalves et al. 2009).

The reduction of biomass by seedlings of $G$. hirsutum caused by cadmium was not significant in studies reported by Ozyigit et al. (2013) for fresh and dried aerial part (leaves) exposed to 0.1 and $0.2 \mathrm{mM}$ cadmium. However, under this concentration, cultivars (cv. NDM9 and cv. GXM3) showed reduced leaf growth by $45.2 \%$ and $40.8 \%$, respectively (Liu et al., 2016). However significant intolerance was observed in roots of G. hirsutum ((ZMS-49) at $0.5 \mathrm{mM}$ (Khan et al. 2013).

Studies with other species show similar effect trends such as T. aestivum (Guilherme et al. 2015), Jatropha curcas (Chaves; Souza, 2014), Phaseolus vulgaris L. (Santos et al. 2013) and Brassica juncea (L.) Hook.f. \& Thomson (Augusto et al. 2014).

Most plants have a low tolerance to cadmium and higher levels of metals in roots than in shoots (Guimarães et al. 2008). The tolerance to cadmium of many plant species is related to the compartmentalization of the metal in the cellular vacuole (Hartke, 2012).

According to Guimarães et al. (2008), the ability plants to survive and prevail in environments rich in heavy metals, where most plants fail to survive, provides a study model system able to detect the mechanisms contributing to tolerance related to transport of metals.

According to Sá et al. (2011), cadmium affects photosynthesis, respiration and the activity of enzymes associated with the antioxidant system of the plant. These effects cause a reduction in the capacity to absorb micronutrients (Guimarães et al. 2008) and water, hindering growth and decreasing the thickness of root tissues proportionally to increasing doses of cadmium.

\section{Conclusions}

Cadmium is a heavy metal toxic even at low concentrations. Cadmium cause toxic effects on the initial development of $G$. hirsutum reducing the percentage of germination and root length at concentration $1.0 \mathrm{mM}$.

The identification of plants tolerant to cadmium allows developing a cultivar that does not concentrate contaminating metals in plant parts and seeds consumed by humans and animals.

\section{References}

An M, Wei C, Wang K, Fan H \& Wang X. 2020. Study on the effects of polymer modifiers and phloem girdling on cotton in cadmium-contaminated soil in Xinjiang Province, China. Scientific Reports 10: 6356. https:// doi.org/10.1038/s41598-020-63421-w

Augusto AS, Bertoli AC, Cannata MG, Carvalho R \& Bastos ARR. 2014. Avaliação dos efeitos tóxicos de $\mathrm{Cd}$ e $\mathrm{Pb}$ na cultura da mostarda (Brassica juncea). Revista Engenharia Sanitária e Ambiental 19: 61-68. https://doi.org/10.1590/S1413-41522014019010000 266

Aycicek M, Ince M \& Yaman M. 2008. Effects of Cadmium on the Germination, Early Seedling Growth and Metal Content of Cotton (Gossypium hirsutum L.). International Journal of Science \& Technology 3 (1): 1-11.

Aycicek M, Kaplan O \& Yaman M. 2008. Effect of Cadmium on Germination, Seedling Growth and Metal Contents of Sunflower (Helianthus annus L.) Asian Journal of Chemistry 20 (4): 2663-2672.

Bautista OV, Fischer G \& Cárdenas JF. 2013. Cadmium and chromium effects on seed germination and root elongation in lettuce, spinach and Swiss chard. Agronomía colombiana 31 (1): 48-57.

Brasil. 2009. Ministério da Agricultura, Pecuária e Abastecimento. Regras para análise de sementes. Ministério da Agricultura, Pecuária e Abastecimento. Secretaria de Defesa Agropecuária. Brasília: MAPA/ ACS.

Chaves LHG \& Souza RS. 2014. Crescimento, distribuição e acumulação de cádmio em plantas de Jatropha curcas. Revista de Ciências Agrárias 37(3): 286-291.

Chen Z, Zhao Y, Fan L, Xing L \& Yang Y. Cadmium (Cd) Localization in Tissues of Cotton (Gossypium hirsutum L.), and Its Phytoremediation Potential for Cd-Contaminated Soils. 2015. Bulletin of Environmental Contamination and Toxicology 95: 784-789. http://dx.doi.org/10.1007/s00128-015-1662-x

Faizan S, Kausar S \& Perveen R. 2011. Varietal differences for cadmium-induced seedling mortality, foliar toxicity symptoms, plant growth, proline and nitrate reductase activity in chickpea (Cicer arietinum L.). Biology and Medicine 3 (2): 196-206.

Farooq MA, Ali S, Hameed A, Bharwana SA, Rizwan M, 
Ishaque M, . . Iqbal Z. 2016. Cadmium stress in cotton seedlings: Physiological, photosynthesis and oxidative damages alleviated by glycinebetaine. South African Journal of Botany 104: 61-68. http://dx.doi.org/10.1016/j.sajb.2015.11.006

Ferreira RL \& Novembre ADLC. 2016. Estimativa do vigor das sementes e das plântulas de Bixa orellana L. Revista Ciência Agronômica 47(1): 101-107. https://doi.org/10.5935/1806-6690.20160012

Gonçalves JF, Maldaner J, Rossato LV, Tabaldi LA, Skrebsky EC, Farias JG, . . Nicoloso FT. 2009. Crescimento in vitro de plântulas de batata em diferentes doses de cádmio. Ciência Rural 39(9): 2625-2628. http://dx.doi.org/10.1590/S010384782009000900038.

Gordin CRB, Marques RF, Masetto TE \& Scalon SPQ. 2012. Germinação, biometria de sementes e morfologia de plântulas de Guizotia abyssinica Cass. Revista Brasileira de Sementes 34 (4): 619627. http://dx.doi.org/10.1590/S0101-312220120004 00013.

Guilherme MFS, Oliveira HM \& Silva E. 2015. Cadmium toxicity on seed germination and seedling growth of wheat Triticum aestivum. Acta Scientiarum. Biological Sciences 37 (4): 499-504. https://doi. org/ 10.4025/actascibiolsci.v37i4.28148.

Guimarães MA, Santana TA, Silva EV, Zenzeni IL \& Loureiro ME. 2008. Toxicidade e tolerância ao cádmio em plantas. Revista Trópica: Ciências Agrárias e Biológicas 3(1): 58-68.

Hartke S. 2012. Caracterização da função e expressão de genes em resposta ao cádmio no tomateiro. Porto Alegre: Universidade Federal do Rio Grande do Sul. Dissertação de Mestrado.

Heidari M \& Serani S. 2011. Effects of lead and cadmium on seed germination, seedling growth and antioxidant enzymes activities of mustard (Sinapis arvensis L.). Journal of Agricultural and Biological Science 6(1): 44-47.

Hosseini Z, Nadian H \& Heidari M. 2012. Effect of cadmium levels on seed germination and seedling growth of Spinach (Spinacia oleracea) under salinity stress. World Applied Sciences Journal 18(3): 332335.

Khan MD, Mei L, Ali B, Chen Y, Cheng X \& Zhu, SJ. 2013. Cadmium-Induced Upregulation of Lipid Peroxidation and Reactive Oxygen Species Caused Physiological, Biochemical, and Ultrastructural Changes in Upland Cotton Seedlings. BioMed Research International 374063: 1-10. http://dx.doi. org/10.1155/2013/374063

Liu LT, Sun HC, Chen J, Zhang YJ, Wang XD, Li DX \& Li CD. 2016. Cotton seedling plants adapted to cadmium stress by enhanced activities of protective enzymes. Plant Soil and Environment 62 (2): 80-85. http://dx.doi.org/10.17221/706/2015-PSE

Lopes KP, Bruno RLA, Costa RF, Bruno GB \& Rocha, MS. 2006. Efeito do beneficiamento na qualidade fisiológica e sanitária de sementes do algodoeiro herbáceo. Revista Brasileira de Engenharia Agrícola e Ambiental 2 (10): 426-435. http://dx.doi.org/10. 1590/S1415-43662006000200025.

Maguire J. 1962. Speed of germination aid in selection and evaluation for seedling and vigour. Crop Science 2 (2): 176-177. http://dx.doi.org/10.2135/ cropsci1962.0011183X000200020033x.

Melo LCA, Silva EB \& Alleoni LRF. 2014. Transfer of cadmium and barium from soil to crops grown in tropical soils. Revista Brasileira de Ciência do Solo 38: 1939-1949. https://doi.org/10.1590/S0100-0683 2014000600028.

Oliveira AKM, Souza JS, Carvalho JMB \& Souza SA. 2015. Germinação de sementes de pau-de-espeto (Casearia gossypiosperma) em diferentes temperaturas. Revista Floresta 1(45): 97-106. https://doi. org/10.5380/rf.v45i1.27599.

Ozyigit II, Vardar F, Yasar U \& AkinciLong S.T LongTerm Effects of Aluminum and Cadmium on Growth, Leaf Anatomy, and Photosynthetic Pigments of Cotton. 2013. Communications in Soil Science and Plant Analysis 44(21): 3076-3091. https://doi.org/10. 1080/00103624.2013.832770

Pereira ERL, Cruz CS, Vilar AT, Socorro RM \& Medeiros MB. 2012. Crescimento inicial do algodoeiro cv. Brs aroeira em diferentes níveis de salinidade. Revista Verde de Agroecologia e Desenvolvimento Sustentável 7(3): 41-45.

Sá TCLL, Marques M, Soares AM, Gomes MP \& Martins G. (2011). Respostas fisiológicas e anatômicas de plantas jovens de eucalipto expostas ao cádmio. Revista Árvore 35 (5): 997-1006. https://doi.org/10. 1590/S0100-67622011000600005.

Santos AP, Fagan EB, Teixeira WF, Soares LH, Reis MR \& Corrêias LT. 2013. Influência de doses de cádmio na emergência e no crescimento do feijoeiro. Revista do Centro Universitário de Patos de Minas 4: 1-8.

Sousa LBO. 2010. Algodoeiro: alguns aspectos importantes da cultura. Revista Verde de Agroecologia e Desenvolvimento Sustentável 5(4): 19-26.

Tao L, Guo M \& Ren J. (2015). Effects of cadmium on seed germination, coleoptile growth, and root elongation of six pulses. Polish Journal of Environmental Studies 24 (1): 295-299. https://doi. org/10.15244/pjoes/29942. 